\title{
UNDERSTANDING
}

ADMINISTRATIVE SILENCE:

A VIEW OF PUBLIC OFFICERS

FROM THE SUBCARPATHIA

\author{
Agata Jurkowska-Gomułka \\ Ph.D. (dr. hab.), Associate Professor, University \\ of Information Technology and Management. \\ Address: 35-335, 2 Sucharskiego Str., Rzeszow, Poland. \\ E-mail: ajurkowska@wsiz.edu.pl
}

\section{Kamilla Kurczewska}

Ph.D., Lecturer, University of Information

Technology and Management.

Address: 35-335, 2 Sucharskiego Str., Rzeszow, Poland.

E-mail: kkurczewska@poczta.onet.pl

\section{Katarzyna Kurzępa-Dedo}

Ph.D., Assistant Professor, University of Information

Technology and Management.

Address: 35-335, 2 Sucharskiego Str., Rzeszow, Poland.

E-mail: kkurzepa@wsiz.edu.pl

\begin{abstract}
This paper presents attitudes of public officers employed in public administrative institutions in Subcarpathia (a region in southeast Poland) towards administrative silence. As a background to the problem, the paper provides characteristics of the legal environment in which the Polish public administration operates regarding administrative silence. In the Polish legal system, administrative silence is expressed and described by different linguistic terms; there are also a variety of possible reactions to it. It causes not only different interpretations of legal regulation concerning the silence, but it also prevents a universal application of these provisions by public administration. The research aimed at determining what kinds of situations are recognised by Subcarpathian public officers as administrative silence (as defined in the Polish Administrative Procedure Code), what types of reactions towards administrative silence most frequently occur, and if there are any internal measures to counteract the silence. The paper concludes with the authors' assessment of the appropriateness of the current Polish regulatory framework on administrative silence for everyday practice of regional public administration in Subcarpathia. The authors conclude that legislation does not facilitate Subcarpathian public officers to correctly understand the consequences of administrative silence. This conclusion can be broadened to public administration in other Polish regions.
\end{abstract}


Keywords: administrative procedure; administrative silence; inactivity; inaction; governmental administration; self-governmental administration.

Citation: Jurkowska-Gomułka, A., Kurczewska, K. \& Kurzępa-Dedo, K. (2020). Understanding Administrative Silence: A View of Public Officers from the Subcarpathia. Public Administration Issues, no 6 (Special Issue II, electronic edition), pp. 98-117 (in English), DOI: 10.17323/1999-5431-2020-0-6-98-117.

\section{Introduction}

Administrative silence is a complex phenomenon lacking a universal definition. In the simplest manner, administrative silence can be defined as a nonfulfilment of an obligation to act by a public administration. Such a broad definition covers various categories of administrative silence - from a silence that is subject to legal consequences (strictly prescribed by law) to silence that is not recognised as such in law but that is negatively assessed by the society as a blameworthy inaction.

The goal of this paper is to describe administrative silence as one of the dimensions of public administration's functioning. The paper proposes a view of the issue from the inside of public administration. One problem raised in the article could be defined as a 'behavioural attitude towards administrative silence' among officials of local public administration, with regard to the legal system in Poland. The authors claim that even if the Polish Code of Administrative Procedure (CAP; Consolidated text: Journal of Laws (JoL) 2020, item 256) provides sufficient rules to counteract administrative silence (rules on elimination of administrative inaction and sanctions for being silent), the phenomenon of administrative silence is still ambiguously interpreted by public officials, mainly because of a lack of a single definition of administrative silence.

The paper gathers the results of a survey conducted in public administration bodies located in Subcarpathia, an administrative region in southeast Poland. The survey focused on how officials understand the concept of administrative silence and their personal experiences regarding administrative silence.

The research was divided into two stages: the first stage involved the legal background of administrative silence in Poland, specifically in the CAP, and the second stage involved a survey conducted among public officers from the Subcarpathian province. The first stage of research aimed at verifying the thesis that the Polish administrative law operates on a multitude of notions and phrases describing administrative silence, resulting in the lack of a commonly recognised (even inside public administration) definition of administrative silence. The research covered conceptual analysis of the literature and systematic analysis of the Polish legal framework. The latter involved identification of a normative description of administrative silence in Polish legal acts by searching electronic databases of Polish law in January-March 2018. The research on the legal framework covered solely laws (acts adopted by the Parliament) - 1,433 acts at the time of research (June 2018, verified in May 2019). 
Identification of a normative framework seems to be important, because Polish public administration has been functioning for dozens of years due to a strong paradigm of acting within and on the basis of law in compliance with a literal interpretation of the law. Analysis of the contents of legal acts required an application of mixed methods of searching (machine and non-machine search) because of the specific character of the Polish language and a style of law-making in Poland that does not allow for creating a selected group of normative acts categorised as 'law of public administration'. In the first stage of research, among 1,433 acts (laws being in force), all the acts containing words with cores of words used for describing 'silence' (inaction) and laws referring to silence/inactivity of public administration were selected.

Results of the first stage of the research became a conceptual base for conducting the second stage of the research by a survey, which was administered from March to June 2018 in selected public administration units in Subcarpathia. The province, located in southeast Poland, bordering Ukraine and Slovakia, is inhabited by $2,129,138$ people. With a capital in Rzeszow City, it covers $17,846 \mathrm{~km}^{2}$ (5.7\% of the surface of Poland). It is considered one of the most dynamically developing provinces in Poland. The province is divided into 25 territorial units of a middle level (PL: powiaty), including four towns with a status of poviats, and 159 territorial units of the lowest level (communes; PL: gminy). A sector of public administration in the Subcarpathian province employs ca. 32,788 people $^{1}$ in either regional delegations of governmental administration or regional/ local self-governmental authorities.

The survey covered 227 persons in 13 public administration units: 92 persons (40.5\%) from a governmental administration and 135 persons (59.5\%) from selfgovernmental administration. Respondents (70.9\% women; $29.1 \%$ men) were employees (public officers in general and specialised governmental administration [regional or local representation thereof]) and self-governmental administration. The survey was conducted using the 'paper and pencil' method, with use of anonymous questionnaires.

The questionnaire contained nine questions focusing on the personal understanding of the term 'administrative silence', the most common reasons for administrative silence, the most common reactions to administrative silence from either clients or institutions, and instruments to combat and prevent administrative silence. Questions represented three categories: (1) single-answer questions (individual answers exclude themselves and contain statements such as 'I do not know' or 'I have no opinion'); (2) multiple choice questions; and (3) ranking questions.

Conducting the survey faced a few barriers. Because of the extremely hierarchical structure and mode of functioning of regional and local public administration, in many institutions the persons taking the survey could not have direct contact with public officers, since questionnaires could have reached them only through supervisors of organisational units. This barrier had a special importance for ranking-type questions because a few participants of the survey did not seem to correctly understand the way these questions should be answered. Another barrier, of a more general nature, was the negative connotation of administrative 
silence; persons under survey could have tried to reduce the meaning and effects of this negative phenomenon in their institutions.

The paper is divided into five sections. After the short introduction, that also contains a description of a scope of the empirical research, review of the literature on administrative silence is presented. In the third section, the paper presents a multitude of recognitions of administrative silence in the Polish administrative law. In this section, the paper specifies different types of public administration's reactions to various reflections of administrative silence. It also proposes a categorisation of these reactions. The last part of the third section is dedicated to a presentation of regulations of CAP concerning administrative silence. In the fourth section, the concept of administrative silence, identified in Polish law, is confronted with the view of this concept expressed by the public officers employed in local public administration who were surveyed. The fifth section presents conclusions.

\section{Literature review}

Public administration is predominantly considered as an activity (Skulová, Potěšil, Hejč \& Bražin, 2019). Administrative silence is rarely raised as an issue in international literature. Legal writings provide many definitions of administrative silence, usually strictly linked to a specific legal culture. The lack of a single definition of administrative silence results in a variety of possible reactions to inactivity of public administration. Among the many different aspects of administrative silence, an excessive length of administrative proceedings seems to be the most often recognised and the most widely analysed in legal writings (Kotulski, 2015; Sever, Đanić \& Kovač, 2016). Other aspects of administrative silence reflected in deeper research considerations are models of administrative silence (Kovač et al., 2020), the unlawfulness of administrative silence (Jansen, 2015), a party's (of administrative proceeding) rights in a situation of administrative silence, and details of a particular legal solution (e.g., positive fiction) to counteract or combat negative effects of administrative silence (Cevallos Gorozabel, Quiñonez Francis \& Castle Cevallo, 2017; Kubiak, 2009; Parisio, 2013; Saddy, 2012; Wagner (2020)). An overall view on this legal, political, and social phenomenon is even more unique (Anthony, 2008; Batalli, 2017; Kovać, 2011). Moreover, the majority of writings in this area were specific to national legal systems (e.g. Rozsnyai \& Hoffman, 2020) and used to be published in national languages (e.g., in Polish: Bochenek, 2003; Gniady, 2019; Gurba, 2015; Kotulski, 2015; Kubiak, 2009; Miłosz, 2011; Dobosz 2011, Suwaj, 2014; Wagner, 2020) - a breakthrough in this regard came in 2020 (Dragos et al, 2020). Personal views of public officers on administrative silence are uniquely presented in the literature (however, see Olsen, 2017), even if personal perspective becomes an important framework for understanding governance (Ford \& Ihrke, 2019).

\section{Administrative silence in Polish law: linguistic and functional perspective}

Legal acts adopted before 1989 (the year when the first democratic parliamentary elections were organised, regarded as the year of the shift from communism 
to democracy as a political system) did not pay much attention to administrative silence. Under the political system enforced until 1989, public administration was considered as a solid monument, granted with instruments of highly proceduralised forms of activities, usually based on power (imperium). The universal means for contesting time-excessive administrative proceedings and administrative silence was only citizens' complaints and motions, formalised in Part II of the Code of Administrative Procedure. In this period, a few Polish lawyers (Janowicz, 1987; Jendrośka, 1979; Starościak, 1978) presented the effects of their research on 'targeted' administrative silence (understood as a lack of activities regardless of a duty to act). All of these authors assessed administrative silence negatively as a nonactivity (in particular areas) that was contrary to law. They also pointed out disciplinary responsibility as a sanction for administrative silence.

Since 1989 (i.e. in the 1990s), the model of public administration in Poland has changed. It transformed from the state (rather than public) administration executing goals of the central government to public administration whose aim was the delivery of services for a society by fulfilling public tasks established in accordance with the subsidiarity principle that became a constitutional rule (Constitution of the Republic of Poland dated 2 April 1997 (JoL 2017, no. 78, item 483). Public administration, instead of acting formally according to procedures, had to deal with new types of activities (and duties) resulting from the new public management and imposition of duties related to the new role of governing a development (Act of 6 December 2006 on principles for conducting a development policy, consolidated text: JoL 2019, item 1295) and managing resources. Supervisors of public administration units have been obliged to fulfil duties of establishing the missions and visions of their units (Act of 27 August 2009 on public finance, consolidated text: JoL 2019, item 869). Even if administrative silence in this area was noticed by controlling authorities, there were no effective legal tools to prevent it or to combat its negative effects.

After 2000, a concept of good governance and multilevel governance became an important dimension of the assessment of public administration in Poland. This approach has been reflected in a growing number of legal institutions imposing new duties to act on public administration's side, such as public discussion (Act of 27 March 2003 on Spatial and Land Use Planning, consolidated text: JoL 2020, item 293), local initiatives (Act of 24 April 2003 on Activity for Public Benefit and Volunteering; consolidated text: JoL 2020, item 1057 as amended); citizens' participation (Act of 20 February 2015 on Local Development with Participation of Local Society, consolidated text: JoL 2019, item 1167, and Act of 9 October 2015 on Revitalisation, consolidated text: JoL 2020, item 802, 1086); the duty of consulting; the right of active participation in meetings of collective organs of public administration; citizens' budget; and other solutions introduced by the Act of 11 January 2018 on Amending Some Acts in Order to Enhance Citizens' Participation in Process of Selection, Functioning and Control of Some Public Organs (JoL 2018, item 130, 1349). These legal institutions should be considered as 'communication channels' for an administered community to express its expectations towards public administration if the latter does not act according to the needs of the community. A specific feature of new regulations is that new 
duties and possibilities introduced in legal acts are usually not connected with an introduction or a reference to any institutions that allow for acting in a situation when public administration will not implement new duties imposed by the new law; such measures can appear at a later stage when the inactivity of public administration has particularly negative effects on a community.

Regarding the above characteristics of a legal environment, the research question was to what extent administrative silence. It is reflected in existing Polish law in 2018. Normative descriptions in Polish legal acts (laws), being in force at the time of the search (June 2019, verified in May 2019), were identified with 14 keywords listed in Table 1 below.

More than 250 legal acts (out of 1,433 laws) - not including the Polish Administrative Procedure Act - contain at least one of these terms, while some acts use more than one term to describe administrative silence.

Table 1

\section{Phrases linked to administrative silence in the Polish legal framework}

\begin{tabular}{|c|c|}
\hline Specific phrase concerning administrative silence & $\begin{array}{l}\text { Number of legal acts containing } \\
\text { the specific phrase }\end{array}$ \\
\hline Non-presentation (PL: nieprzedstawienie) & 37 \\
\hline Non-adoption (PL: niepodjęcie) & 34 \\
\hline Non-submission (PL: nieprzekazanie) & 30 \\
\hline Non-expression (PL: niewyrażenie) & 26 \\
\hline Non-taking (PL: niezajęcie) & 25 \\
\hline Non-adaption (PL: niewydanie) & 24 \\
\hline Inaction (PL: bezczynność) & 21 \\
\hline $\begin{array}{l}\text { Silent resolvement of the case (PL: milczace załatwienie sprawy) } \\
\text { Silence (PL: milczenie) }\end{array}$ & 19 \\
\hline Non-notification (PL: niezgłoszenie) & 16 \\
\hline Non-fulfilment (PL: niewykonanie) & 11 \\
\hline Non-grant (PL: nieudzielenie) & 7 \\
\hline $\begin{array}{l}\text { Lack (PL: brak) in relation to other phrases, such as: } \\
\text { Lack of implementation (PL: brak wdrożenia) } \\
\text { Lack of adoption (PL: brak wydania) } \\
\text { Lack of presentation (PL: brak przedstawienia) }\end{array}$ & 6 \\
\hline Overdue/excessive length (PL: przewlekłość) & 6 \\
\hline Non-implementation (PL: niewdrożenie) & 3 \\
\hline $\begin{array}{l}\text { Non-proving of a sufficient effectiveness (PL: niewykazanie } \\
\text { dostatecznej skuteczności) }\end{array}$ & 2 \\
\hline
\end{tabular}

Source: Everywhere, unless otherwise specified - research by authors. 
The research proved the existence of a multitude of descriptions of situations that can be considered as administrative silence. A collection of these phrases creates a diverse picture of administrative silence in Polish legal acts.

Reactions to administrative silence and the effects of administrative silence are also described diversely. However, within this multitude of descriptions, it is possible to select certain types of reactions/effects and legal tools used for combating and/or preventing administrative silence.

Table 2

\section{Consequences of administrative silence in the Polish legal framework (examples)}

\begin{tabular}{|c|c|}
\hline Specific phrase concerning consequences of administrative silence & $\begin{array}{l}\text { Types of reactions } \\
\text { to administrative } \\
\text { silence/types of tools } \\
\text { used for combating } \\
\text { and/or preventing } \\
\text { administrative } \\
\text { silence }\end{array}$ \\
\hline $\begin{array}{l}\text { 'is not a barrier' (PL: nie stanowi przeszkody) } \\
\text { 'does not suspend a resolvement of a case' (PL: nie wstrzymuje rozpoznania) } \\
\text { 'does not delay further works' (PL: nie wstrzymuje prac) } \\
\text { 'does not suspend an adoption of a decision' (PL: nie wstrzymuje wydania decyzji) } \\
\text { 'does not delay a proceeding' (PL: nie wstrzymuje postępowania) } \\
\text { 'A requirement for getting an opinion is considered as fulfilled' (PL: wymóg } \\
\text { zasięgnięcia opinii uznaje się za spetniony) }\end{array}$ & $\begin{array}{l}\text { Silence = elimination } \\
\text { of a certain } \\
\text { activity from } \\
\text { an administrative } \\
\text { proceeding }\end{array}$ \\
\hline $\begin{array}{l}\text { 'means a lack of remarks' (PL: oznacza brak uwag) } \\
\text { 'means a lack of reservations' (PL: oznacza brak zastrzeżeń) } \\
\text { 'means a lack of remarks and reservations' (PL: oznacza brak uwag i zastrzeżeń) } \\
\text { 'is considered as a lack of reservations' (PL: uznaje się za brak zastrzeżeń) } \\
\text { 'is treated as a lack of reservations' (PL: traktuje się jako brak zastrzeżeń) } \\
\text { 'It is considered that this entity does not make any reservations' (PL: przyjmuje } \\
\text { się, że podmiot ten nie składa zastrzeżeń) }\end{array}$ & $\begin{array}{l}\text { Silence }=\text { considered } \\
\text { as a lack of any } \\
\text { comments/remarks }\end{array}$ \\
\hline $\begin{array}{l}\text { 'means a resignation of a right to express an opinion' (PL: oznacza rezygnację } \\
z \text { prawa do wyrażenia opinii) }\end{array}$ & $\begin{array}{l}\text { Silence = considering } \\
\text { resignation } \\
\text { of the right to take } \\
\text { a particular position } \\
\text { in a case }\end{array}$ \\
\hline $\begin{array}{l}\text { 'is equal to accepting an application' (PL: jest równoznaczne z akceptacja wniosku) } \\
\text { 'is recognised as an acceptance' (PL: uznaje się za akceptację) } \\
\text { 'is recognised as an accord' (PL: uznaje się za uzgodnienie) } \\
\text { 'is recognised as an expression of an accord' (PL: uznaje się za wyrażenie zgody) } \\
\text { 'is recognised as an expression of a positive opinion' (PL: uznaje się za wyrażenie } \\
\text { opinii pozytywnej) } \\
\text { 'a condition is considered as fulfilled' (PL: uznaje się wymóg za spełniony) } \\
\text { 'It is claimed that an opinion is positive' (PL: uważa sie że opinia jest pozytywna) } \\
\text { 'It is claimed as equal to a positive opinion in a case' (PL: uważa się } \\
z a \text { równoznaczne z pozytywnym zaopiniowaniem) } \\
\text { 'is regarded as an accord on a project' (PL: uważa się za uzgodnienie projektu) } \\
\text { 'It is acknowledged that an opinion is positive' (PL: przyjmuje się, że opinia jest } \\
\text { pozytywna) }\end{array}$ & $\begin{array}{l}\text { Silence = acceptance, } \\
\text { accord }\end{array}$ \\
\hline
\end{tabular}




\begin{tabular}{|c|c|}
\hline Specific phrase concerning consequences of administrative silence & $\begin{array}{l}\text { Types of reactions } \\
\text { to administrative } \\
\text { silence/types of tools } \\
\text { used for combating } \\
\text { and/or preventing } \\
\text { administrative } \\
\text { silence }\end{array}$ \\
\hline $\begin{array}{l}\text { [supervisory organ] 'establishes independently' (PL: [organ nadzorczy] } \\
\text { samodzielnie ustala) } \\
\text { [supervisory organ] 'issues an order' (PL: [organ nadzorczy] } \\
\text { wydaje zarządzenie) } \\
\text { [a person pointed by law] 'executes' (PL: [osoba wyznaczona ustawa] } \\
\text { wykonuje) }\end{array}$ & Subsidiary execution \\
\hline $\begin{array}{l}\text { 'a complaint to the administrative court' (PL: skarga do sadu administracyjne) } \\
\text { 'an appeal to the administrative court' (PL: odwołanie do saqdu administracyjnego) } \\
\text { 'a reminder' (PL: ponaglenie) }\end{array}$ & $\begin{array}{l}\text { Complaints } \\
\text { to appropriate organs/ } \\
\text { institutions }\end{array}$ \\
\hline $\begin{array}{l}\text { 'financial penalty' (PL: grzywna) } \\
\text { 'fine' (PL: kara pieniężna) }\end{array}$ & Financial sanctions \\
\hline $\begin{array}{l}\text { 'a call for an execution of tasks' (PL: wezwanie do wykonania zadań) } \\
\text { 'a notification to supervisory organs' (PL: zawiadomienie organów nadzorczych) } \\
\text { 'a subsidiary order' (PL: zarządzenie zastępcze) } \\
\text { 'a suspension of organs - appointing a subsidiary management' (PL: zawieszenie } \\
\text { organów - wyznaczenie zarządu komisarycznego) } \\
\text { 'calling a person off a function of an organ' (PL: odwołanie osoby z funkcji } \\
\text { organu) } \\
\text { 'dissolving an employment contract without a termination period by a fault } \\
\text { of an employee' (PL: Rozwiązanie stosunku pracy bez wypowiedzenia z winy } \\
\text { pracownika) } \\
\text { 'a revocation of an accreditation' (PL: cofnięcie akredytacji) }\end{array}$ & Supervisory measures \\
\hline 'granting compensation on the basis of Civil Code (Art $417 \mathrm{ff.}$ )' & Civil liability \\
\hline $\begin{array}{l}\text { 'disciplinary responsibility (from a caveat to a dismissal)' (PL: odpowiedzialność } \\
\text { dyscyplinarna od upomnienia do zwolnienia) }\end{array}$ & $\begin{array}{l}\text { Disciplinary } \\
\text { responsibility }\end{array}$ \\
\hline 'criminal liability' & Penal liability \\
\hline
\end{tabular}

The research shows that in sustentative Polish administrative law there is no universal model of attitude/reactions towards a non-fulfilment (by public administration) of duties directly expressed in law. Many laws provide instruments oriented for accelerating administrative procedures where a lack of activity 'is considered as an acceptance', the procedure 'goes on despite a lack of, and 'is considered as a lack of any reservations'. If an activity of a public administration authority is necessary, the Polish lawmakers also predicted such instruments as complaints to a court or fines and financial penalties in order to guarantee an efficient closure of a case to a party.

Another instrument for combating negative results of administrative silence is expressed in laws mainly as 'considered as accepted' and 'considered 
as approved'. This instrument is present in more than 50 laws, but it is used rather incidentally, not as a rule.

In many laws, one can find instruments in the form of 'a notification to supervisory institution' and 'disciplining instruments': from an order to undertake an action, through subsidiary execution to a suspension of organs or appointing a subsidiary management. 'Subsidiary execution' (understood as an activity of a certain public administration institution instead of an institution primarily obliged to act) can be applied in few cases, almost solely in relations between administrative authorities. However, in a great number of laws there are no measures on preventing and/or combating administrative silence. An organ that wants to co-operate can, then, potentially use universal instruments of supervision in public administration and notify an inactivity of a certain organ to a supervisory organ. This mode of action is described mainly in internal regulations and guidelines - separately in governmental and self-governmental administrations (the only area of regulation at the parliamentary level, by-laws, is the supervision of governmental administration over self-governmental administration).

At the most general level, the Polish Code of Administrative Procedure provides regulations on the control of timeliness of public administration that can be controlled through: urging (Art. 37 of CAP) as well as a complaint on administrative silence (Art. $3 \$ 2$ points 8-9, Art. $54 \$ 3$ Law on Judicial Administrative Procedure (JAP) ${ }^{1}$, a fine (Art. $154 \$ 6$ of JAP) and a claim for a damage (Art. $154 \$ 6$ JAP). In 2017 a tacit authorization was introduced into Art. 122a-122f CAP. It can be applied only if specific laws explicitly state so (Gniady, 2020; Jakubowski, 2020; Jurkowska-Gomułka et al., 2020; Kmieciak, 2019).

\section{Administrative silence: personal perspectives of public officers in the Subcarpathian province}

Regarding the chaotic approach of Polish lawmakers towards administrative silence (multitude of phrases describing the phenomenon, either in substantive administrative law or in the light of CAP; various kinds of reactions to administrative silence), the question on the attitude of public officers towards the problem of administrative silence is important and was reflected in the second stage of the research.

Firstly, public officers were asked about their personal definition of the concept of administrative silence. The questionnaire offered six answers, giving the possibility to choose more than one of them.

The majority of respondents consider administrative silence as a lack of any activity of public administration in individual cases. The least number of choices concerned defining administrative silence as a lack of activities aimed at building public policies.

1 Consolidated text: JoL 2018, item 1302. 


\section{Question 1. The concept of administrative silence should be understood as:}

\begin{tabular}{|l|c|}
\hline \multicolumn{1}{|c|}{ Answer } & Share of the particular answer, \% \\
\hline $\begin{array}{l}\text { Lack of any activities of public administration in an individual case } \\
\text { Lack of any activity of public administration in a certain area } \\
\text { of problems (e.g., spatial planning) }\end{array}$ & 33.8 \\
\hline $\begin{array}{l}\text { Lack of any activity of public administration shaping public policy } \\
\text { Lack of any activity of public administration if a public authority } \\
\text { is obliged to act }\end{array}$ & 28.8 \\
\hline $\begin{array}{l}\text { Lack of any activity of public administration if a public authority } \\
\text { is not obliged to act }\end{array}$ & 28.9 \\
\hline Excessive length of administrative proceeding & 11.4 \\
\hline
\end{tabular}

The survey showed that administrative silence is understood diversely by public officers from governmental and self-governmental administrations. Public officers offered the third answer (lack of any activity of public administration shaping public policy) most frequently: $100 \%$ of managers of the middle level, $62.5 \%$ of managers, and $53.6 \%$ of specialists chose this answer. The second choice of the respondents from governmental administration was the first answer, focusing on a lack of activity in an individual case. Within self-governmental administration, the first answer was the most common (61.1\% of middle-level managers, $66.7 \%$ of managers, and $63.7 \%$ of specialists chose this answer), whereas the third answer was the second choice for this group.

Further, respondents were asked about their personal assessment of reasons for administrative silence and intentions for administrative silence. The majority expressed an opinion that a lack of activity in more than 50\% of cases (63.4\%) is unintentional, and only $20.3 \%$ assume that there is a conscious intention behind administrative silence. But more than $16.3 \%$ of respondents do not have an opinion of the reasons for administrative silence. Seemingly, the respondents understood 'unintentional' administrative silence as inaction caused by reasons lying totally beyond the reach of public officers (or even public administration, as such).

Table 4

Question 2. In the majority of cases (over 50\%), administrative silence is:

\begin{tabular}{|l|c|}
\hline \multicolumn{1}{|c|}{ Answer } & Share of a particular answer, \% \\
\hline Intentional and targeted & 20.3 \\
\hline Unintentional & 63.4 \\
\hline I have no opinion & 16.3 \\
\hline
\end{tabular}


Respondents were also asked to rank selected reasons for administrative silence from the most to the least frequent. The majority of public officers $(43.6 \%)$ considered unclear content of legal provisions as the most common cause for a lack of activity of public administration (only 7.9\% suggested it as the least frequent reason). Rankings of other reasons were more balanced; for example, insufficient human resources were considered as the first (the most common) reason by $30.4 \%$ of respondents and as the least important reason by $17.6 \%$. Too short a period for completing the case was even more 'democratically' considered as the most common reason for administrative silence by $20.3 \%$ of respondents and the least frequent by $22.9 \%$ of respondents. Only $7.5 \%$ of respondents ranked as the first a lack of an institution's conviction for a certain solution, but, surprisingly, $24.3 \%$ ranked this reason as the second in a row. The analysis of answers in both pillars of public administration showed that representatives of governmental administration ranked the second answer (insufficient human resources) as the most important reason $(38 \%)$ and unclear content of regulations as the reason of second importance (34.8\%), whereas self-governmental administration pointed out the third answer (on unclear content) as the most frequent reason $(49.6 \%$ ), and insufficient human resources was the second-choice answer for this group (25.2\%). The conclusion is rather simple, although alarming: self-governmental administration declares more problems with the interpretation of regulations while dealing with administrative cases.

Table 5

\section{Question 3. Considering reasons for administrative silence pointed out} below, inaction of public administration is most frequently caused by

(answers ranked: 1 - the most frequent reason, 4 - the rarest reason;

rank 0 in tables below refers to a share of respondents who did not choose a particular answer)

\begin{tabular}{|c|}
\hline Too short a period (prescribed by law) to close a case: \\
Rank 1: $20.3 \%$ \\
Rank $2: 27.8 \%$ \\
Rank $3: 18.1 \%$ \\
Rank $4: 22.9 \%$ \\
Rank $0: 11 \%$ \\
\hline Insufficient human resources: \\
Rank 1: $30.4 \%$ \\
Rank $2: 17.2 \%$ \\
Rank $3: 26.4 \%$ \\
Rank $4: 17.6 \%$ \\
Rank $0: 8.4 \%$ \\
\hline Unclear content of legal provisions being the basis for a final decision: \\
Rank $1: 43.6 \%$ \\
Rank $2: 18.9 \%$ \\
Rank $3: 24.7 \%$ \\
Rank $4: 7.9 \%$ \\
Rank $0: 4.8 \%$ \\
\hline
\end{tabular}


Lack of institution's conviction for a certain solution:

Rank 1: $7.5 \%$

Rank 2: $24.3 \%$

Rank 3: $14.6 \%$

Rank 4: $42.9 \%$

Rank 0: $10.6 \%$

Some questions concentrated on the problem of clients' attitude towards administrative silence. Regarding 'emotional' aspects, $41.4 \%$ of respondents experienced anger of clients as their reaction to administrative silence; $13.1 \%$ experienced a reaction described as disappointment and discouragement; and only $7.1 \%$ of respondents faced a certain level of understanding from clients. According to public officers' opinions, the most common reaction of clients is a claim lodged within an internal structure of an institution. Only $6.7 \%$ of respondents held that disappointed or angry clients applied to an administrative court, and $9.4 \%$ of respondents pointed out appealing to the media as a response to administrative silence.

Table 6

\section{Question 4. What was the most common reaction of clients of public administration towards administrative silence that you experienced in your professional practice?}

\begin{tabular}{|l|c|}
\hline \multicolumn{1}{|c|}{ Answer } & Share of the particular answer, \% \\
\hline Anger & 41.4 \\
\hline Disappointment and discouragement & 13.1 \\
\hline Understanding & 7.1 \\
\hline $\begin{array}{l}\text { Complaint to supervisors (within internal institutional } \\
\text { structure) }\end{array}$ & 22.3 \\
\hline Complaint to administrative court & 6.7 \\
\hline Contact with the media & 9.4 \\
\hline
\end{tabular}

Anger and a complaint addressed to supervisors (within an internal structure) were pointed out by a similar number of respondents from governmental and self-governmental administrations ( $79.5 \%$ and $82.1 \%$, respectively). However, more persons from a self-governmental administration (29.9\% to $19.3 \%)$ chose an attitude of disappointment and discouragement as the most common reaction to administrative silence. Perhaps this choice was somehow driven by the fact that public officers from the self-governmental administrations under survey were in a majority of cases engaged in direct relationships with clients. More public officers from governmental administration than public officers from selfgovernment (18.2\% to $9.7 \%)$ pointed to a complaint to an administrative court as a common client response to administrative silence, which may be explained by categories of cases: in the survey, governmental financial administrations 
were strongly represented, and in social insurance or tax cases clients usually have much stronger incentive to act. The same argument can be applied towards the noticeable difference between governmental (28.4\%) and self-governmental (11.9\%) administration regarding a choice of a contact with the media as a reaction to administrative silence (probably, mistakes by financial (governmental!) administration are really what the media are interested in).

A few questions concerned institutional reaction to administrative silence directed to a particular employee held responsible for a lack of activity. The first question focused on supervisors' responses to the behaviour of employees resulting in administrative silence. The questionnaire offered a choice of six answers, and the last one was formulated in an open manner; a respondent had the possibility to add any types of reaction specific to her/his institution. The most common reaction of supervisors to a situation resulting in administrative silence was a reprimand; $61.7 \%$ of respondents ranked it as the first, but $16.7 \%$ did not mention it at all. Financial sanctions, such as fines or a decrease of income, seem to be the least popular; $67 \%$ of respondents did not mention them at all, although this type of sanction was mentioned more often by public officers of self-governmental administration (from various levels). Only 8.4\% of respondents claimed that a transfer of a case to another employee or another department was a reaction to non-action in an institution. Apologies to a client also do not seem to be very common in public administration in the Subcarpathian province; only $6.6 \%$ of surveyed public officers ranked it as the first, $9.7 \%$ as the second, $14.5 \%$ as the third, and $13.2 \%$ as the fourth. Apologies seem to be more common among public officers of governmental administration $(65.2 \%)$ than among public officers from self-governmental administrations. What is striking in the analysis of answers to this question is that a high number of respondents $(63 \%)$ did not rank any particular sanction. It proves that reactions to behaviour causing administrative silence are not standardised in public administration and probably not very common.

Table 7

Question 5. What supervisor reaction to a behaviour of an individual employee, resulting in administrative silence, do you observe the most often in your institution?

(answers ranked: 1 - the most frequent reaction, 4 - the rarest reaction):

\begin{tabular}{|c|}
\hline Reprimand: \\
Rank 1: $61 \%$ \\
Rank $2: 9.7 \%$ \\
Rank $3: 6.2 \%$ \\
Rank $4: 5.7 \%$ \\
Rank $0: 16.7 \%$ \\
\hline Non-financial sanctions, other than a reprimand: \\
Rank $1: 9.3 \%$ \\
Rank $2: 20.7 \%$ \\
Rank $3: 18.1 \%$ \\
Rank $4: 8.4 \%$ \\
Rank $0: 43.6 \%$ \\
\hline
\end{tabular}




\begin{tabular}{|c|}
\hline $\begin{array}{l}\text { Financial sanctions: } \\
\text { Rank 1: } 2.6 \% \\
\text { Rank } 2: 4.4 \% \\
\text { Rank } 3: 8.4 \% \\
\text { Rank } 4: 17.2 \% \\
\text { Rank } 0: 67.0 \%\end{array}$ \\
\hline $\begin{array}{l}\text { Transfer of a case to another person or department in order to close it: } \\
\qquad \begin{array}{c}\text { Rank } 1: 8.4 \% \\
\text { Rank } 2: 20.7 \% \\
\text { Rank } 3: 15.4 \% \\
\text { Rank } 4: 11.5 \% \\
\text { Rank } 0: 67.0 \%\end{array}\end{array}$ \\
\hline $\begin{array}{l}\text { Requirement of apologies for a client: } \\
\qquad \begin{array}{c}\text { Rank 1: } 6.6 \% \\
\text { Rank } 2: 9.7 \% \\
\text { Rank } 3: 14.5 \% \\
\text { Rank } 4: 13.2 \% \\
\text { Rank 0: } 55.9 \%\end{array}\end{array}$ \\
\hline $\begin{array}{l}\text { No reaction: } \\
\text { Rank } 1: 11.1 \% \\
\text { Rank } 2: 5.8 \% \\
\text { Rank } 3: 4.0 \% \\
\text { Rank } 4: 15.5 \% \\
\text { Rank } 0: 63.7 \%\end{array}$ \\
\hline $\begin{array}{l}\text { Other (what types of reactions?): } \\
\text { Rank 1: } 0 \% \\
\text { Rank } 2: 0 \% \\
\text { Rank } 3: 0 \% \\
\text { Rank } 4: 0 \% \\
\text { Rank 0: } 0 \%\end{array}$ \\
\hline
\end{tabular}

Public officers were also asked in the survey to express their opinion on necessary (the most desired) actions that should be applied by public administration. The greatest number of respondents $(62.6 \%)$ ranked as the first giving priority to a case as soon as it is found out that so far an institution has been 'silent'. A much lower number of respondents (30.4\%) mentioned solving a case in a manner that is satisfying for a client as the best reaction of an institution to administrative silence. Financial instruments, in the form of either compensation for clients or a fine imposed on an employee who contributed to administrative silence, were rejected by respondents. In both pillars of public administration, shares of particular answers from the total number of answers were quite close: the most popular response concerned prioritising the case $(70.7 \%$ in governmental administration and $57.0 \%$ in self-governmental administration). Disciplinary proceedings are the least popular measures taken in the case of administrative silence; $54.3 \%$ of public officers from governmental administration and $60.7 \%$ from self-governmental administration did not give this answer at all. The results of the survey in this part suggest that both pillars of public administration - governmental and self-governmental - operate the same model of sanctions for administrative silence. 
Table 8

Question 6. What are the most necessary instruments that should be implemented in the case of administrative silence from a client's point of view? (answers ranked: 1 - the most necessary instrument, 4 - the least necessary instrument)

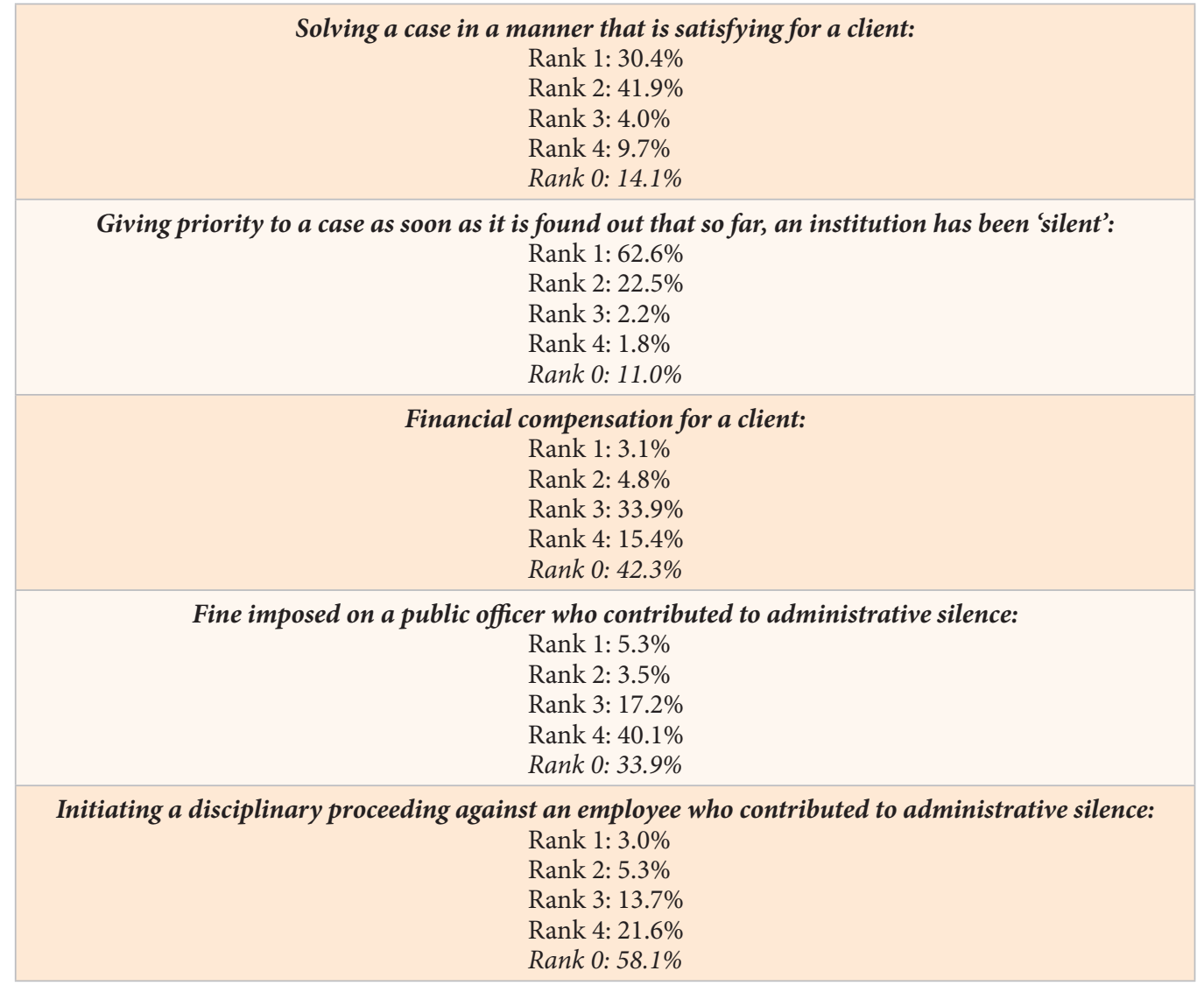

What is astonishing is that when asked about the existence of internal procedures to prevent administrative silence in their institutions, $19.4 \%$ of respondents answered that such procedures were non-existent, and $34.4 \%$ did not know if they existed. A comparison of results from governmental and self-governmental administrations shows that governmental public officers are better oriented on this issue; $60.9 \%$ of them know internal procedures in case of administrative silence, and only $36.3 \%$ of respondents from self-government have any knowledge of such procedures.

Table 9

Question 7. Do you know if any internal procedures preventing administrative silence have been established in your institution?

\begin{tabular}{|c|c|}
\hline Answer & Share of the particular answer, $\%$ \\
\hline Yes & 46.3 \\
\hline No & 19.4 \\
\hline I do not know & 34.4 \\
\hline
\end{tabular}


Public officers from the Subcarpathian province were also asked what category of liability for administrative silence would be the most effective as an instrument for counteracting administrative silence. Answers covering five types of liability (civil liability, financial liability, penal liability, employee's liability, and disciplinary liability) had to be ranked in reference to the effectiveness of the particular category of liability. Almost $1 / 3$ of respondents consider employee's liability (i.e., intra-institutional liability) as the most efficient; $1 / 5$ of respondents consider penal liability as the most appropriate measure to combat administrative silence; and less than $1 / 20$ see civil and penal liability as the most efficient.

Table 10

Question 8. In your view, what categories of liability of public officers for administrative silence are the most efficient measures to counteract administrative silence? (answers ranked: 1 - the most efficient category of liability, 5 - the least efficient category of liability)

\begin{tabular}{|c|}
\hline Civil liability: \\
Rank 1: $7.5 \%$ \\
Rank 2: $9.7 \%$ \\
Rank 3: $22.9 \%$ \\
Rank $4: 24.2 \%$ \\
Rank 0: $19.4 \%$ \\
\hline Financial liability: \\
Rank 1: $21.9 \%$ \\
Rank 2: $19.4 \%$ \\
Rank 3: $14.1 \%$ \\
Rank $4: 14.5 \%$ \\
Rank 0: $17.2 \%$ \\
\hline Penal liability: \\
Rank 1: $20.3 \%$ \\
Rank 2: $22.5 \%$ \\
Rank 3: $16.3 \%$ \\
Rank $4: 7.9 \%$ \\
Rank $0: 18.1 \%$ \\
\hline Employee's liability: \\
Rank $1: 27.8 \%$ \\
Rank 2: $10.6 \%$ \\
Rank 3: $8.4 \%$ \\
Rank $4: 18.1 \%$ \\
Rank 0: $9.7 \%$ \\
\hline Disciplinary responsibility: \\
Rank 1: $16.3 \%$ \\
Rank 2: $20.7 \%$ \\
Rank 3: $18.5 \%$ \\
Rank $4: 15.4 \%$ \\
Rank 0: $14.5 \%$ \\
\hline
\end{tabular}

In the final part of the questionnaire, respondents assessed existing regulations regarding administrative silence. A criterion for this assessment was the effectiveness of these regulations seen as a real tool for preventing ad- 
ministrative silence. It was found that $12.8 \%$ of respondents do not know any regulation on administrative silence, but $40.1 \%$ do not have any opinion of it (31.5\% in governmental administration and $45.9 \%$ in self-governmental administration). A positive opinion on effectiveness of existing regulations was expressed by $43.5 \%$ of respondents in governmental administration and $27.4 \%$ in self-governmental administration. These results confirm that for public officers in the Subcarpathian province, administrative silence seems to be a rather alien topic.

Table 11

\section{Question 9. Do you think that regulations regarding administrative silence are sufficient in terms of their effectiveness in the real prevention of administrative silence?}

\begin{tabular}{|l|c|}
\hline \multicolumn{1}{|c|}{ Answer } & Share of the particular answer, \% \\
\hline Yes & 33.9 \\
\hline No & 13.2 \\
\hline I do not have any opinion & 40.1 \\
\hline $\begin{array}{l}\text { I do not know any legal regulations concerning } \\
\text { administrative silence }\end{array}$ & 12.8 \\
\hline
\end{tabular}

\section{Conclusions}

The research on the Polish legal framework proved that Polish lawmakers operated a great number of instruments for combating or preventing administrative silence. The whole picture is unclear. Each of these instruments is described by different phrases, which makes the practical interpretation of these regulations difficult. Furthermore, some areas of potential administrative silence are worth regulatory intervention, whereas others are not. It seems that, at least in some cases, incentives to introduce a particular measure to counteract administrative silence were society's expectations and dissatisfaction caused by a lack of activity of public administration (an example is a fine of ca. 125 EUR for each day of delay in making an administrative decision on the basis of Construction Law (consolidated text: JoL 2020, item 1333,), as a response to a problem of excessive duration of proceedings regarding construction cases that was negatively assessed by society). In recent years (2010-2017), a tendency in lawmaking was choosing measures/instruments aimed at guaranteeing efficiency and quickness in solving cases rather than forcing an organ to act. The research showed that the Polish legislators introduced plenty of phrases referring to administrative silence in legal acts (e.g., inaction, non-implementation, non-application, non-completion). But these phrases are applied in a chaotic manner, dependent on the linguistic preferences of those drafting legal acts. As a result, the total view of administrative silence in the Polish legal framework seems to be rather incoherent. 
The Polish legal system lacks a systematic approach to administrative silence, even if the latter is understood in a narrow sense as an inaction and nonfulfilment of duties explicitly described in laws. This conclusion is confirmed in the results of the survey covering public officers from regional governmental and self-governmental administrations in Subcarpathia. The concept of administrative silence is not understood in a universal manner. Subcarpathian public officers are not convinced about the efficiency of existing measures to counteract administrative silence, and some of them do not even know these measures (the survey showed a degree of ignorance regarding internal procedures on administrative silence), even if they are established e.g. in CAP that constitutes the key basis for their every day work.

The state of Subcarpathian public officers' awareness regarding administrative silence results from the fact that public administration has been educated in accordance with an execution paradigm, and public officers focus exclusively on procedures attributed to their workplaces. This situation was shaped historically in Poland. The Polish lawmakers also made a choice: instead of introducing instruments universally applied in typical situations, casuistic instruments dedicated to a single law are created. Consequently, the Polish legal system lacks general principles and instruments that would be clear for either public officers or citizens. These characteristics of the Polish legal system are widely reflected in attitudes of public officers in Subcarpathia towards the problem of administrative silence. Surely, the research is worth repeating in other regions of Poland, but assumingly, the results will be rather similar - public officers are uncertain in their knowledge on the definition and the practice of administrative silence.

Undoubtedly, the collection of forms of public administration activities has been permanently growing in recent decades. Therefore, areas of administrative silence have been broadening. Legal means that can be applied for diagnosis and reactions for administrative silence have been adopted, with some delay: under these circumstances, Subcarpathian public officers' ambiguous attitude towards administrative silence can be justified.

\section{Acknowledgments}

The first version of the paper was presented during the Annual Conference of the European Group of Public Administration that was held in Lausanne

(Switzerland), 5-7 September 2018.

The authors are grateful to Dr Elżbieta Inglot-Brzek from the University of Information Technology and Management for her support in the interpretation of the survey results. 


\section{REFERENCES}

1. Anthony, G. (2008). Administrative Silence and UK Public Law. Ideas. Available at: http:// ideas.repec.org/a/pmu/cjurid/v34-35y2008p39-59.html (accessed: 20 August 2018).

2. Batalli, M. (2017). Consequences of Administrative Silence in Public Administration. SEER Journal for Labour and Social Affairs in Eastern Europe, vol. 20, no 1, pp. 139-152. Available at: https://doi.org/10.5771/1435-2869-2017-1-139 (accessed: 20 August 2018).

3. Bochenek, W. (2003). Bezczynność a milczenie organu administracji publicznej [Inaction versus Silence of Administrative Body]. Samorzad Terytorialny, no 12, pp. 41-50.

4. Cevallos Gorozabel, E.M., Quiñonez Francis, H.S. \& Castle Cevallos, C.S. (2017). The Application of the Positive Administrative Silence in the Ecuadorian Legislation. Weber Sociology \& Anthropology, vol. 8, no 1, pp. 824-828.

5. Dragos, D. et al. (eds.) (2020). The Sound of Silence in European Administrative Law. Cham: Palgrave Macmillan.

6. Ford, M. R \& Ihrke, D.M. (2019). Perceptions are Reality: A Framework for Understanding Governance. Administrative Theory and Praxis, vol. 41, no 2, pp. 129-147.

7. Gniady, L. (2020). Stosowanie milczącego załatwienia sprawy administracyjnej w ramach realizacji kompetencji jednostek samorządu terytorialnego [The Application of Tacit Settlement of Administrative Matters within the Framework of Implementing the Competence of Territorial Self-Government Units]. Samorzad Terytorialny, no 1-2, pp. 69-78.

8. Gurba, W. (2015). Zwalczanie i zapobieganie bezczynności oraz przewlekłości postępowania administracyjnego [Combating and Counteracting Administrative Silence and Excessive Administrative Proceeding]. Państwo i Prawo, 11, 94-110.

9. Jakubowski, A. (2020). Problemy z milczącym załatwianiem spraw administracyjnych [Problems with Administrative Silence]. Państwo i Prawo, no 6, pp. 121-134.

10. Janowicz, Z. (1987). Kodeks postępowania administracyjnego. Komentarz [Code of Administrative Procedure. Commentary]. Warszawa Poznań: PWN.

11. Jansen, O. (2015). Silence of the Administration. Maastricht Faculty of Law Working Paper, no 3.

12. Jendrośka, J. (1979). Kompetencje proceduralno-prawne a bezczynność organów administracyjnych [Legal and Procedural Competences and Administrative Silence]. Państwo i Prawo, no 5, pp. 12-17.

13. Jurkowska-Gomułka, A. et al. (2020). Administrative Silence: A Polish Perspective. In: Dragos, D. et al. (eds.) (2020). The Sound of Silence in European Administrative Law. Cham: Palgrave Macmillan, pp. 433-458.

14. Kmieciak, Z. (2019), Zakres stosowania przepisów Kodeksu postępowania administracyjnego o milczącym załatwieniu sprawy [Scope of Application of Code of Administrative Procedure on Tacit Authorization]. Zeszyty Naukowe Sadownictwa Administracyjnego, no 5, pp. 9-23.

15. Kotulski, M. (2015). Bezczynność a przewlekłe prowadzenie postępowania administracyjnego [Administrative Silence and Excessive Administrative Procedure]. Samorzad Terytorialny, no 4, pp. 72-81. 
16. Kovač, P. (2011). Šutnja uprave između teorije i prakse u Sloveniji [Administrative Silence between Theory and Practice in Slovenia]. Zbornik Pravnog fakulteta Sveučilišta u Rijeci, vol. 32, no 9, pp. 869-901.

17. Kubiak, A. (2009). Fikcja pozytywnego rozstrzygnięcia w prawie administracyjnym [Positive fiction in a Decision Based on Administrative Law]. Państwo i Prawo, no 11, pp. 32-46.

18. Mazur, S. (Ed.) (2011). Reformowanie polskiej administracji publicznej - wybrane aspekty, zagadnienia [Reforming Polish Public Administration - Selected Aspects and Issues]. Kraków: Uniwersytet Ekonomiczny.

19. Miłosz, M. (2011). Bezczynność organu administracji publicznej w postępowaniu administracyjnym [Silence of Administrative Body in Administrative Proceeding]. Warszawa: Wolters Kluwer.

20. Olsen, A.L. (2017). Responding to problems: actions are rewarded, regardless of the outcome. Public Management Review, 19, no 9, pp. 1352-1364. Available at: https://doi.org/10.1080/ 14719037.2017.1281998 (accessed: 01 December 2019).

21. Parisio, V. (2013). The Italian Administrative Procedure Act and Public Authorities' Silence. Hamline Law Review, vol. 36, no 1, pp. 3-25.

22. Polish Statistical Office (2018). Statistical bulletin of Podkarpackie Voivodeship (1st quarter 2018). Available at: http://www.bip.podkarpackie.pl/attachments/article/4067/polaczonybiuletyn_i_ kw_2018.pdf (accessed: 08 August 2019).

23. Rozsnyai, K. F., Hoffman, F. (2020). New Hungarian Institutions against Administrative Silence: Friends or Foes of the Parties? Studia Iuridica Lublinensia, vol. 29, no 1, pp. 109-127.

24. Saddy, A. (2012). Administrative Silence in Brazilian Law. Available at: https://works.bepress. com/andre_saddy/1/ (accessed: 21 August 2018).

25. Sever, T., Đanić, A. \& Kovač, P. (2016). Effective Legal Protection Against the Excessive Length of Administrative Decision-Making: The Cases of Slovenia and Croatia. The NISPAcee Journal of Public Administration and Policy, vol. 9, no 1, pp. 135-166. Available at: https:// doi.org/10.1515/nispa-2016-0007 (accessed: 01 December 2019).

26. Skulová, S., Potěšil, L., Hejč, D. \& Bražina, R. (2019). Effectiveness of Judicial Protection Against Administrative Silence in the Czech Republic. Central European Public Administration Review, no 1, pp. 43-68. Available at: https://doi:10.17573/cepar.2019.1.03 (accessed: 01 December 2019).

27. Starościak, J. (1978). Prawo administracyjne [Administrative Law]. Warszawa: PWN.

28. Suwaj, P. (2014). Sadowa ochrona przed bezczynnościa administracji publicznej [Judicial Protection from Administrative Silence]. Warszawa: Wolters Kluwer.

29. Wagner, J. (2020). Instytucja milczacego załatwienia sprawy przez administracje publiczna [Tacit Authorization of Cases by Public Administration]. Warszawa: Wolters Kluwer Polska. 